\title{
Renal Net Glucose Release In Vivo and Its Contribution
}

\section{to Blood Glucose in Rats}

\author{
Kaichi Kida, Shinjiro Nakajo, Fumitada Kamiya, Yoshiko Toyama, Takashi \\ Nishio, and HACHIRo NAKAGawa, Division of Protein Metabolism, Institute for \\ Protein Research, Osaka University, 5311 Yamada-kami, Suita City, \\ Osaka 565, Japan
}

\begin{abstract}
A B S T RACT This study describes the contribution of de novo glucose synthesis by the kidney to blood glucose homeostasis in rats. The net glucose release by the kidney in vivo was measured by an isotope-dilution method, which calculated the extent of dilution of injected $\left[{ }^{14} \mathrm{C}\right]$ glucose by glucose newly synthesized in the kidney. The extent of dilution was determined from the difference between the decrease of the actual blood glucose concentration and that of the radioactivity of $\left[{ }^{14} \mathrm{C}\right]$ glucose, after injecting $\left[{ }^{14} \mathrm{C}\right]$ glucose into functionally hepatectomized rats.
\end{abstract}

The results indicate that the net glucose release by the kidney in vivo in normal fed rats was $0.75 \pm 0.13$ $\mathrm{mg} / \mathrm{dl}$ per min, and that its contribution to blood glucose was $25.9 \pm 5.0 \%$. When unilateral nephrectomy was performed, under the same conditions, renal net glucose release was one-half of that in rats with two intact kidneys, which indicates the quantitative accuracy of the isotope-dilution method employed in this study.

In rats starved for $24 \mathrm{~h}$, the renal net glucose release increased to $0.99 \pm 0.08 \mathrm{mg} / \mathrm{dl}$ per min. Diabetic rats showed a remarkably higher renal net glucose of 2.28 $\pm 0.33 \mathrm{mg} / \mathrm{dl}$ per min, which was $360 \%$ of the normal level. Treatment of diabetic rats with insulin, restored the renal net glucose release to the normal level. In acidotic rats, renal net glucose release was as great as

Dr. Kida's present address is the Department of Pediatrics, Ehime University School of Medicine, Shigenobu-cho, Ehime, Japan. Dr. Nakajo's present address is the Department of Pharmacology, Nihon Veterinary College, Musashino, Tokyo, Japan. Dr. Kamiya's present address is the Department of Medicine, Nagoya City University Medical School, Mizuho-ku, Nagoya, Japan. Dr. Toyama's present address is the Department of Domestic Science, Hyogo Women's Junior College, Kakogawa, Hyogo, Japan. Reprint requests should be addressed to Dr. Nakagawa at the Institute for Protein Research.

Received for publication 30 November 1977 and in revised form 22 May 1978.
$1.03 \pm 0.15 \mathrm{mg} / \mathrm{dl}$ per min, which suggests that the acid-base balance participates in control of renal glucose output. Measurements every $6 \mathrm{~h}$ throughout the day showed that glucose was supplied from the kidney at a constant rate without any circadian rhythm.

These data suggest that renal gluconeogenesis is of physiological importance in the maintenance of homeostasis of blood glucose.

\section{INTRODUCTION}

It is now well established that all the enzymes involved in gluconeogenesis are present in the kidney as well as in the liver, although the liver is thought to be the main site of gluconeogenesis for production of blood glucose (1). In the kidney, the total activity of phosphoenolpyruvate carboxykinase (PEPCK), ${ }^{1}$ a rate-limiting enzyme of gluconeogenesis, is one-fourth of that in the liver $(1,2)$. Furthermore, it has been shown that kidney slices $(3,4)$ or perfused kidney $(5,6)$ can release glucose into the medium when incubated or perfused with various precursors of gluconeogenesis. These data have raised the question of whether the kidney releases enough glucose to contribute to maintenance of homeostasis of the blood glucose level. There have been many attempts to answer this question by measuring the renal venoarterial (RV-A) difference of the glucose concentration, but the very small RV-A difference, as a result of the rapid renal blood flow, has made it difficult to obtain a definite answer (7-11). Bergman and Drury (12) and others (13-15) showed that the decrease in the blood glucose concentration in eviscerated animals with intact kidneys was less than that in completely eviscerated animals, suggesting net glucose release from the kidney. To study this problem, we developed an isotope-dilution method for quantitative determina-

\footnotetext{
${ }^{1}$ Abbreviations used in this paper: PEPCK, phosphoenolpyruvate carboxykinase; RV-A renal venoarterial.
} 
tion of the amount of glucose release from the kidney in vivo. With this method, we attempted to determine the contribution of the kidney to production of blood glucose in rats in the normal state and in abnormal metabolic states, such as diabetes, fasting, or acidosis.

\section{METHODS}

Animals. Male Wistar-HLA strain rats, weighing 200-250 g, were obtained from Japan Animal Co. (Tokyo, Japan), and were given free access to water and laboratory chow $\mathrm{MF}$ (Oriental Yeast Co., Osaka, Japan). The ambient temperature of the animal room was kept at $25 \pm 1^{\circ} \mathrm{C}$, and the lights were switched on from 8:15 a.m. to 8:15 p.m. and off from 8:15 p.m. to $8: 15$ a.m. Diabetes mellitus was produced by injecting $5 \mathrm{mg} / \mathrm{kg}$ body wt of alloxan monohydrate (Sigma Chemical Co., St. Louis, Mo.) intravenously, 1 wk before experiments. The diabetic rats were divided into three groups. The first group was injected subcutaneously with $0.5 \mathrm{U} / \mathrm{kg}$ body wt of Lente-insulin (Novo Research Institute, Copenhagen, Denmark) in $0.2 \mathrm{ml}$ of saline for 3 days. The second group was injected with $0.2 \mathrm{ml}$ of saline for 3 days. The third group was freely given a solution of $75 \mathrm{mM} \mathrm{NaHCO}_{3}$ in drinking water for 3 days and then $2 \mathrm{mmol}$ of $\mathrm{NaHCO}_{3}$ in 5 $\mathrm{ml}$ of water by stomach tube, 16 and $8 \mathrm{~h}$ before experiments. Acidosis was induced by giving a solution of $75 \mathrm{mM} \mathrm{NH} \mathrm{m}_{4} \mathrm{Cl}$ freely for 3 days and then $2 \mathrm{mmol}$ of $\mathrm{NH}_{4} \mathrm{Cl}$ in $5 \mathrm{ml}$ of water by stomach tube, 16 and $8 \mathrm{~h}$ before experiments.

Measurement of net glucose release from the kidney. Rats were anesthetized by intraperitoneal injection of $40 \mathrm{mg} / \mathrm{kg}$ body wt of pentobarbital sodium (Abbott Diagnostics, North Chicago, Ill.) and laparatomized. At zero time, $1 \mu \mathrm{Ci}$ of $\mathrm{D}$ [U- $\left.{ }^{14} \mathrm{C}\right]$ glucose $(230 \mathrm{mCi} / \mathrm{mmol}$, Radiochemical Center, Amersham, England) was injected into the inferior vena cava. After $15 \mathrm{~min}$, functional hepatectomy was performed by ligating the superior and inferior mesenteric arteries, the celiac artery, and the portal vein, and $0.8 \mathrm{ml}$ of blood was taken from a femoral artery; functional nephrectomy was performed by ligating the renal arteries and veins. After 35 min, another $0.8 \mathrm{ml}$ of blood was collected from the abdominal aorta, and then the kidneys were rapidly removed and frozen on dry ice. The serum was separated by centrifugation immediately after collecting the blood.

The principle of calculation of the net glucose release from the kidney ( $\mathrm{R}, \mathrm{mg} / \mathrm{dl}$ per min) is illustrated in Fig. 1 , where $\mathrm{r}(\mathrm{mg} / \mathrm{min})$ and $\mathrm{u}(\mathrm{mg} / \mathrm{min})$ indicate the absolute net glucose release from the kidney and the utilization of glucose in the tissues, respectively. When the total amounts of the radioactive and nonradioactive glucose at the time $t$ ( $t$ minutes after the functional hepatectomy) are given as $y(t)$ and $x(t)$, respectively, $y(t+d t)$ and $x(t+d t)$ at time $t+d t$ can be expressed as follows:

$$
\begin{aligned}
& y(t+d t)=y(t)-\frac{y(t)}{x(t)+y(t)} \mathrm{u} d t \\
& x(t+d t)=x(t)+\mathrm{r} d t-\frac{x(t)}{x(t)+y(t)} \mathrm{u} d t
\end{aligned}
$$

Eqs. 1 and 2 are transformed to:

$$
\begin{aligned}
& \frac{d y}{d t}=\frac{-y}{x+y} \mathrm{u} \\
& \frac{d x}{d t}=\mathrm{r}-\frac{x}{x+y} \mathrm{u}
\end{aligned}
$$

The resolution of the differential Eqs. 3 and 4 gives $R$ and

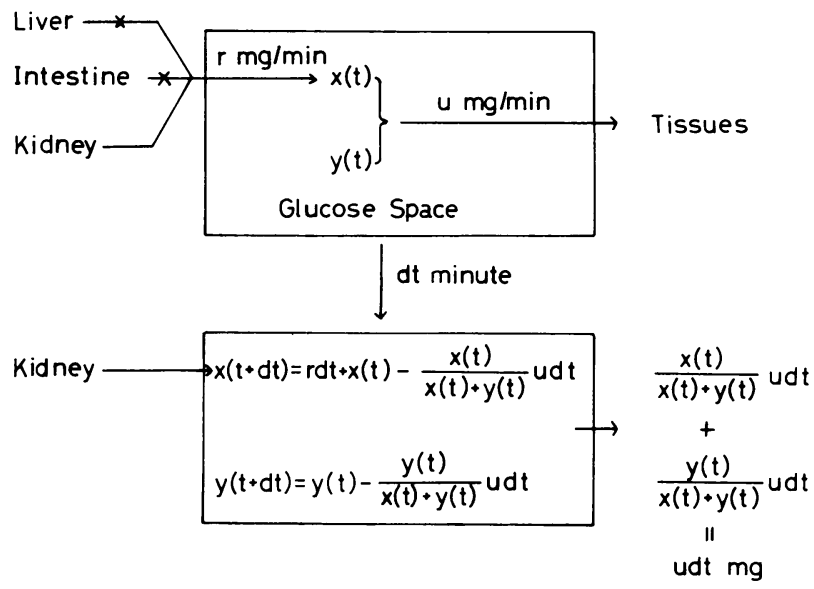

Figure 1 Principle of the isotope-dilution method for measurement of renal net glucose release in vivo. $x(t)$, $x(t+d t)$; the amounts of unlabeled glucose in the glucose space $(\mathrm{mg})$ at times $t$ and $t+d t . y(t), y(t+d t)$; the amounts of labeled glucose in the glucose space $(\mathrm{mg})$ at times $t$ and $t+d t$. $\mathrm{r}$; glucose release from the kidney into the glucose space. $u$; glucose utilization in tissues.

$\mathrm{U}$, as follows:

$\mathrm{R}(\mathrm{mg} / \mathrm{dl}$ per $\mathrm{min})$

$$
\begin{gathered}
\frac{\left(x_{0}+y_{0}\right)-\left(x_{20}+y_{20}\right)}{t_{20}}\left(\frac{\log \frac{y_{20}}{y_{0}}}{\left.\log \frac{x_{20}+y_{20}}{x_{0}+y_{0}}-1\right)}\right. \\
=\frac{X_{0}-X_{20}}{20}\left(\frac{\log \frac{Y_{20}}{Y_{0}}}{\log \frac{X_{20}}{X_{0}}}-1\right) .
\end{gathered}
$$

$$
\begin{array}{r}
\mathrm{U}\left(\mathrm{mg} / \mathrm{dl} \text { per } \min =\frac{\left(x_{0}+y_{0}\right)-\left(x_{20}+y_{20}\right)}{t_{20}} \frac{\log \frac{y_{20}}{y_{0}}}{\log \frac{x_{20}+y_{20}}{x_{0}+y_{0}}}\right. \\
=\frac{X_{0}-X_{20}}{20} \frac{\log \frac{Y_{20}}{Y_{0}}}{\log \frac{X_{20}}{X_{0}}},
\end{array}
$$

where $Y_{0}$ and $Y_{20}$ are the radioactivities (counts per minute) of $\left[{ }^{14} \mathrm{C}\right]$ glucose, and $X_{0}$ and $X_{20}$ are the blood glucose concentrations (milligrams per deciliter) at 0 and $20 \mathrm{~min}$, respectively, after functional hepatectomy. Accordingly, the relative contribution of the kidney to the supply of blood glucose $(C$; percent) can be expressed by the following formula:

$$
\mathrm{C}(\%)=\frac{\mathrm{R}}{\mathrm{U}} \times 100=\frac{\log \frac{X_{20}}{X_{0}}-\log \frac{Y_{20}}{Y_{0}}}{\log \frac{X_{20}}{X_{0}}} \times 100 .
$$

Regin-Hexokinase method for measurement of radioactivity of ${ }^{14} \mathrm{C}$-labeled glucose. The radioactivity of ${ }^{14} \mathrm{C}$-labeled glu- 
cose in the blood was determined by the Regin-Hexokinase method. The principle and procedure of this method are as follows: $0.2 \mathrm{ml}$ of serum that contains ${ }^{14} \mathrm{C}$-labeled substances, such as glucose, lactate, pyruvate, and amino acids, is applied to a first Dowex- 2 column $\left(0.5 \times 4 \mathrm{~cm}, \mathrm{Cl}^{-}\right.$-form, Dow Corning Corp., Midland, Mich.), on which substances with a negative charge are adsorbed, and the column is eluted with $4 \mathrm{ml}$ of water. The eluate, which contains unadsorbed ${ }^{14} \mathrm{C}$-labeled substances, is incubated at $37^{\circ} \mathrm{C}$ for $5 \mathrm{~min}$ with $5 \mathrm{mM}$ ATP, $15 \mathrm{mM} \mathrm{MgCl}, 1 \mathrm{mM}$ dithiothreitol, and $20 \mathrm{U}$ of hexokinase (Boehringer Mannheim Yamanouchi Co., Tokyo, Japan) in a final vol of $4.5 \mathrm{ml}$, to convert ${ }^{14} \mathrm{C}$-labeled glucose to ${ }^{14} \mathrm{C}$ labeled glucose-6-phosphate. This incubation mixture is then applied on a second Dowex-2 column. Substances which were not adsorbed on the first Dowex-2 column pass through the second Dowex-2 column and only ${ }^{14} \mathrm{C}$-labeled glucose6-phosphate is adsorbed. The column is washed with $4 \mathrm{ml}$ of water and then the adsorbed ${ }^{14} \mathrm{C}$-labeled glucose-6-phosphate is eluted with $4 \mathrm{ml}$ of $0.5 \mathrm{~N} \mathrm{HCl}$. The eluate is mixed with 10 $\mathrm{ml}$ of PCS (Amersham/Searle Corp., Arlington Heights, Ill.) in a vial and counted in a Packard 1130 Liquid-Scintillation Spectrometer (Packard Instrument Co. Inc., Downers Grove, Ill.). There is a linear relationship between the amount of ${ }^{14} \mathrm{C}$-labeled glucose added to normal rat serum and the radioactivity measured as ${ }^{14} \mathrm{C}$-labeled glucose by this method. The SEM of measured values was less than $1.5 \%(n=4)$ and the recovery of radioactivity was $94 \pm 1.5 \%$ ( \pm SEM). The specificity of the Regin-Hexokinase method was tested by adding ${ }^{14} \mathrm{C}$-labeled lactate, pyruvate, glycerol, alanine, glutamine, glutamate, aspartate, serine, glycine, or sodium bicarbonate to normal rat serum, and then measuring the ${ }^{14} \mathrm{C}$-labeled glucose in the serum. With these compounds, no radioactivity was detected as ${ }^{14} \mathrm{C}$-labeled glucose. This shows that the Regin-Hexokinase method is specific for ${ }^{14} \mathrm{C}$-labeled glucose.

Other procedures. For determination of the RV-A difference in glucose concentration in normal fed rats, $0.2 \mathrm{ml}$ samples of blood were taken simultaneously from the abdominal aorta and the renal vein. Glucose concentration was measured by the glucose-oxidase method (16). The $\mathrm{pH}$ of blood withdrawn anaerobically from the femoral artery was measured with Blood Gas Analyzer MK2 (Radiometer Co., Copenhagen, Denmark). PEPCK was assayed as described previously (17). Protein concentration was measured by the microBiuret method (18). Statistical significance was assessed as outlined by Snedecor and Cochran (19) and by Mainland (20).

\section{RESULTS}

Renal net glucose release in normal rats. In normal fed rats, the apparent renal glucose release (A) was calculated to be $1.16 \pm 0.12 \mathrm{mg} / \mathrm{dl}$ per min from Eq. 5 . However, a calculated value of $0.41 \pm 0.14 \mathrm{mg} / \mathrm{dl}$ per $\min (B)$ was obtained even when both the liver and the kidneys were functionally removed. This might be because of leakage of glucose synthesized in the liver from the ligated vessels or to glucose synthesized elsewhere, but it was almost constant from one experiment to another. Thus the true net glucose release from the kidney was obtained by subtracting value (B) from value (A). As shown in Table $I$, in normal fed rats this value was $0.75 \pm 0.13 \mathrm{mg} / \mathrm{dl}$ per min and the contribution of renal gluconeogenesis to blood glucose was calculated to be $25.9 \pm 5.0 \%$ from Eq. 7 . The quantita- tive accuracy of this isotope-dilution method was examined by measuring renal net glucose release and its contribution to blood glucose in rats in which one kidney had been functionally removed. The values obtained were approximately one-half of those in rats with two intact kidneys (Table I). The RV-A difference for the glucose concentration in normal fed rats was $3.9 \pm 1.0 \mathrm{mg} / \mathrm{dl}(n=6)$.

Renal net glucose release in starved, diabetic, and acidotic rats. Renal net glucose release in starved, diabetic, and acidotic rats was calculated by subtracting value (B) from value (A) for each group. In rats that had been starved for $24 \mathrm{~h}$, the renal net glucose release increased considerably to $0.99 \pm 0.08 \mathrm{mg} / \mathrm{dl}$ per min, compared with the value of $0.57 \pm 0.10 \mathrm{mg} / \mathrm{dl}$ per min observed in normal fed rats in the same experiment (Table II). In alloxan diabetic rats, whose blood glucose concentration was $550 \pm 69 \mathrm{mg} / \mathrm{dl}$, the renal net glucose release was increased to $2.28 \pm 0.33 \mathrm{mg} / \mathrm{dl}$ per min which accounts for $55.3 \pm 8.0 \%$ of the blood glucose. When diabetic rats were treated with $0.5 \mathrm{U} / \mathrm{kg}$ body wt of Lente-insulin for 3 days, their renal net glucose release returned to the normal level. When diabetic rats were treated with sodium bicarbonate for 3 days, the renal net glucose release decreased to $1.88 \pm 0.25 \mathrm{mg} / \mathrm{dl}$ per min, though it was still greater than the normal level (Table III). In acidosis induced by oral administration of ammonium chloride solution

\section{TABLE I}

Renal Net Glucose Release and its Contribution to Blood Glucose in Normal Fed Rats

\begin{tabular}{cccc}
\hline \multicolumn{1}{c}{ Treatment } & $\begin{array}{c}\text { Apparent } \\
\text { glucose } \\
\text { release }\end{array}$ & $\begin{array}{c}\text { Net } \\
\text { glucose } \\
\text { release }\end{array}$ & $\begin{array}{c}\text { Contribution } \\
\text { to blood } \\
\text { glucose }\end{array}$ \\
\hline $\begin{array}{l}\text { Hepatectomy } \\
+ \text { bilateral } \\
\text { nephrectomy } \\
(n=5)\end{array}$ & $\mathrm{mg} / \mathrm{dl} / \mathrm{min}$ & $\mathrm{mg} / \mathrm{dl} / \mathrm{min}$ & $\%$ \\
$\begin{array}{l}\text { Hepatectomy } \\
+ \text { unilateral } \\
\text { nephrectomy } \\
(n=5)\end{array}$ & $0.41 \pm 0.14$ & - & - \\
$\begin{array}{l}\text { Hepatectomy } \\
+ \text { no nephrec- } \\
\text { tomy }(n=4)\end{array}$ & $1.16 \pm 0.12$ & $0.75 \pm 0.13$ & \\
\end{tabular}

$1 \mu \mathrm{Ci}$ of $\left[\mathrm{U}-{ }^{14} \mathrm{C}\right]$ glucose was injected into the inferior vena cava of anesthetized rats, and functional hepatectomy was carried out $15 \mathrm{~min}$ later. Arterial blood was taken 0 and 20 min after hepatectomy and the glucose concentration and radioactivity of glucose were determined. Renal net glucose release and its contribution to blood glucose were calculated as described in the text. Values are means \pm SEM. Differences from the value of the control are statistically significant. ${ }^{*} P<0.05$. 
TABLE II

Renal Net Glucose Release and its Contribution to Blood Glucose in Starved Rats

\begin{tabular}{cccc}
\hline Treatment & $\begin{array}{c}\text { Net } \\
\text { glucose } \\
\text { release }\end{array}$ & $\begin{array}{c}\text { Contribution } \\
\text { to blood } \\
\text { glucose }\end{array}$ & $\begin{array}{c}\text { Activity of } \\
\text { PEPCK }\end{array}$ \\
\hline & $m g / d l / m i n$ & $\%$ & $n m o l / m i n / m g$ \\
Normal $(n=5)$ & $0.57 \pm 0.10$ & $21.5 \pm 3.5$ & $18.5 \pm 1.7$ \\
Starved $(n=5)$ & $0.99 \pm 0.08 *$ & $46.6 \pm 4.3 \ddagger$ & $46.6 \pm 6.7 \ddagger$ \\
\hline
\end{tabular}

Rats were starved for $24 \mathrm{~h}$. Renal net glucose release and its contribution to blood glucose were measured as described in the legend to Table I. Values are means \pm SEM. Differences from the value of the control are statistically significant.

$* P<0.02$.

$\neq P<0.005$.

for 3 days, the renal net glucose release was calculated to be $1.03 \pm 0.15 \mathrm{mg} / \mathrm{dl}$ per min. This value was $160 \%$ greater than the normal level observed in this experiment (Table IV). In all three conditions, starvation, diabetes, and acidosis, where the renal net glucose release increased, the activity of renal PEPCK, a ratelimiting enzyme of gluconeogenesis, was enhanced significantly (Tables II-IV).

Circadian rhythm of renal net glucose release. We reported previously (2) that PEPCK activity in rat kidney showed a circadian rhythm with the highest activity at 2:00 a.m. and the lowest activity at 2:00 p.m. We, therefore, examined whether the renal net glucose release also showed a circadian fluctuation with the same pattern as the enzyme rhythm. We found, however, that the renal supply of glucose and its contribu- tion to blood glucose were constant throughout the day, without any significant circadian rhythm, as shown in Fig. 2.

\section{DISCUSSION}

From results obtained in vitro by enzyme assays, and experiments on tissue slices and perfused kidney, it has been suggested that renal gluconeogenesis contributes to maintenance of the blood glucose level in vivo (1-6). This conclusion is supported by the findings of Bergman and Drury (12), Reinecke (13), Smith and Long (14), and Archer et al. (15) that the decrease in blood glucose level after evisceration was less in rats with intact kidneys than in nephrectomized animals. Reinecke (7), Steiner et al. (8), Bollman and Grindlay (9), McCann and Jude (10), and Churchill et al. (11) measured the RV-A difference for glucose concentration to elucidate the renal contribution to the blood glucose level. They showed that the glucose concentration in renal venous blood was greater than that in aortic blood, but the difference was not statistically significant, presumably because of the quantitative imprecision caused by rapid renal blood flow. Moreover, even when their assay error was reduced, the RV-A difference was nullified in normal animals when the value for the concentration of glucose in venous blood was corrected for urine formation (11). Their findings are inconsistent with previous ones.

To resolve this complex problem, we developed a highly sensitive and accurate isotope-dilution method. We also reduced the effect of surgical stress by employing functional hepatectomy in place of surgical evisceration. With these methods, we obtained strong

TABLE III

Renal Net Glucose Release and its Contribution to Blood Glucose in Diabetic Rats

\begin{tabular}{lcccc}
\hline \multicolumn{1}{c}{ State } & $\begin{array}{c}\text { Net glucose } \\
\text { release }\end{array}$ & $\begin{array}{c}\text { Contribution } \\
\text { to blood } \\
\text { glucose }\end{array}$ & $\begin{array}{c}\text { Concentration } \\
\text { of blood } \\
\text { glucose }\end{array}$ & $\begin{array}{c}\text { Activity of } \\
\text { PEPCK }\end{array}$ \\
\hline & $m g / d l / m i n$ & $\%$ & $m g / d l$ & $n m o l / m i n / m g$ \\
Normal $(n=5)$ & $0.63 \pm 0.18$ & $28.9 \pm 6.9$ & $130 \pm 10$ & $21.1 \pm 1.4$ \\
Diabetic $(n=6)$ & $2.28 \pm 0.33^{*}$ & $55.3 \pm 8.0 \ddagger$ & $550 \pm 69 \S$ & $44.7 \pm 4.2 \S$ \\
Diabetic + insulin $(n=5)$ & $0.72 \pm 0.20^{\prime \prime}$ & $28.1 \pm 8.0^{\prime \prime}$ & $184 \pm 32^{\prime \prime}$ & $28.5 \pm 4.0^{\prime \prime}$ \\
Diabetic $+\mathrm{NaHCO}_{3}(n=5)$ & $1.88 \pm 0.25^{*}$ & $48.2 \pm 5.1 \ddagger$ & $480 \pm 88^{*}$ & $36.0 \pm 5.4 \ddagger$
\end{tabular}

Diabetes was induced by intravenous injection of $0.5 \mathrm{mg} / \mathrm{kg}$ body weight of alloxan 1 wk before experiments. Diabetic rats were treated intraperitoneally with $0.5 \mathrm{U} / \mathrm{kg}$ body wt of Lente-insulin or orally with sodium bicarbonate for 3 days. Renal net glucose release and its contribution to blood glucose were measured as described in the legend to Table I. Values are means \pm SEM. Differences from the value of the control are statistically significant.

$* P<0.005$.

$\neq P<0.05$.

$\$ P<0.001$.

"NS. 
TABLE IV

Renal Net Glucose Release and its Contribution to Blood Glucose in Acidotic Rats

\begin{tabular}{lcccc}
\hline \multicolumn{1}{c}{ Treatment } & $\begin{array}{c}\text { Net glucose } \\
\text { release }\end{array}$ & $\begin{array}{c}\text { Contribution } \\
\text { to blood } \\
\text { glucose }\end{array}$ & $\begin{array}{c}\text { Activity of } \\
\text { PEPCK }\end{array}$ & pH of blood \\
\hline & $m g / d l / m i n$ & $\%$ & $n m o l / m i n / m g$ & \\
$\mathrm{NaCl}(n=5)$ & $0.63 \pm 0.10$ & $27.1 \pm 4.3$ & $38.4 \pm 4.2$ & $7.40 \pm 0.01$ \\
$\mathrm{NH}_{4} \mathrm{Cl}(n=5)$ & $1.03 \pm 0.15^{*}$ & $47.3 \pm 5.9 \ddagger$ & $57.2 \pm 6.5^{*}$ & $7.24 \pm 0.03 \S$ \\
\hline
\end{tabular}

Acidosis was induced by oral administration of ammonium chloride solution for 3 days. Renal net glucose release and its contribution to blood glucose were measured as described in the legend to Table I. Values are means \pm SEM. Differences from the value of the control are statistically significant.

$* P<0.05$.

$\ddagger P<0.02$.

$\S P<0.001$.

evidence for a significant contribution of renal gluconeogenesis to the maintenance of blood glucose homeostasis. Our results indicated that $25.9 \%$ of the blood glucose was produced in the kidney in normal fed rats. This value coincided well with the finding in enzyme studies that the total activity of PEPCK in the kidney was one-fourth of that in the liver in normal fed rats $(2,21)$.

We observed a significant positive RV-A difference in glucose concentration of $3.9 \pm 1.0 \mathrm{mg} / \mathrm{dl}$. By assuming that renal blood flow is $5.2 \mathrm{ml} / \mathrm{min}$ per $100 \mathrm{~g}$ body weight (22), the renal net glucose release was calculated from the RV-A difference in glucose concentration to be $0.21 \pm 0.05 \mathrm{mg} / \mathrm{min}$ per $100 \mathrm{~g}$ body wt. On the other hand, the value for renal net glucose release obtained by the isotope-dilution method in this work was $0.75 \pm 0.13 \mathrm{mg} / \mathrm{dl}$ per min. By taking the glucose space as $33.0 \mathrm{ml} / 100 \mathrm{~g}$ body wt (23), the absolute value for renal net glucose release was calculated to be $0.24 \pm 0.04 \mathrm{mg} / \mathrm{min}$ per $100 \mathrm{~g}$ body wt. This value obtained by the isotope-dilution method agrees well with the value obtained from the RV-A difference in glucose concentration.

It was shown that renal net glucose release increased to $0.99 \pm 0.08 \mathrm{mg} / \mathrm{dl}$ per min when rats were starved for $24 \mathrm{~h}$. From this value, the contribution of renal gluconeogenesis to blood glucose was calculated to be $46.6 \%$ during starvation. In studies on the RV-A difference in glucose concentration in humans, Owen et al. (24) found that $45 \%$ of the blood glucose formed endogenously was produced by the kidney during prolonged starvation. Thus their results are very similar to ours on starved rats.

Our study showed that when diabetic rats were treated with insulin, their renal net glucose release returned to the normal level. Furthermore, the renal net glucose release was greatly increased in rats made acidotic by oral administration of ammonium chloride.
This finding agrees with the report of Goodman et al. (25) that the RV-A difference in glucose concentration was greater in acidotic animals. Accordingly, the acid-base balance is probably important in regulating renal net glucose release in vivo, in addition to influencing humoral factors, such as insulin, glucagon, and glucocorticoids.

Nagai et al. (2) reported that PEPCK activity in the kidney showed a circadian rhythm, closely related with food intake with the highest activity at 2:00 a.m. and the lowest activity at 2:00 p.m. Unexpectedly, however, we could detect no circadian change in renal net glucose release. In other words, we found that the kidney supplied glucose at a constant rate throughout the day, and showed no relation to the rhythm of food intake or activity of the animals. On the other hand, our studies indicate that hepatic glucose release probably does have a circadian rhythm, because the total glucose

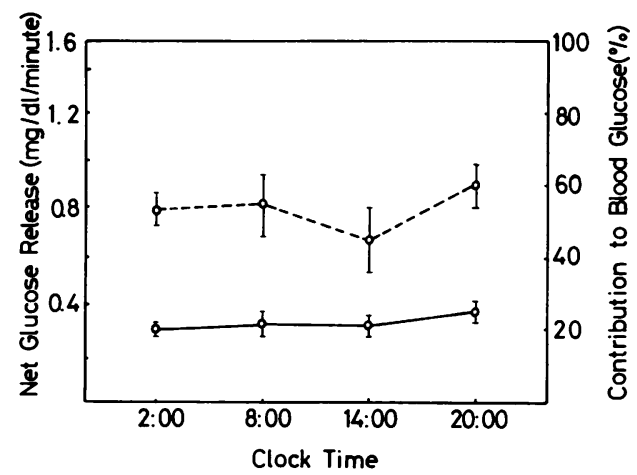

Figure 2 Circadian rhythm of renal net glucose release and its contribution to blood glucose. Renal net glucose release and its contribution to blood glucose were measured every $6 \mathrm{~h}$, as described in the legend to Table $\mathrm{I}$. The dotted line represents the renal net glucose release and the solid line represents the contribution to blood glucose. Vertical bars show \pm SEM. 
released from the liver and intestine is unchanged throughout the day (Fig. 2), but that released from the intestine should be highest during the night when animals eat and lowest in the evening before they eat. We also showed that the hepatic conversion of precursors to glucose in vivo had a circadian rhythm, which was highest in the evening and lowest in the early morning, like the circadian rhythm of hepatic PEPCK activity. ${ }^{2}$ We conclude from these data that the liver and kidney work coordinately in maintaining blood glucose homeostasis. The liver supplies glucose with a circadian rhythm in response to the nutritional state of the animals, while the kidney supplies blood glucose steadily to meet the minimal requirement in normal fed rats. Further experiments are needed to determine the mechanism which controls renal net glucose release in vivo.

\section{ACKNOWLEDGMENTS}

We are grateful to Dr. D. S. Goodman of Columbia University College of Physicians \& Surgeons and Dr. Y. Yasojima of Mitsubishi Electric Co., Ltd., Japan for their helpful discussions.

\section{REFERENCES}

1. Scrutton, M. C., and M. F. Utter, 1968. The regulation of glycolysis and gluconeogenesis in animal tissues. Annu. Rev. Biochem. 37: 249-302.

2. Nagai, K., M. Suda, O. Yamagishi, Y. Toyama, and H. Nakagawa. 1975. Studies on the circadian rhythm of phosphoenolpyruvate carboxykinase. III. Circadian rhythm in the kidney. J. Biochem. (Tokyo). 77: 1249-1254.

3. Benoy, M. P., and K. A. C. Elliott. 1937. The metabolism of lactic and pyruvic acids in normal and tumor tissue. V. Synthesis of carbohydrate. Biochem. J. 31: 1268-1275.

4. Krebs, H. A., D. A. H. Bennett, P. DeGasquet, T. Gascoyne, and T. Yoshida. 1963. Renal gluconeogenesis: The effect of diet on the gluconeogenic capacity of rat-kidneycortex slices. Biochem. J. 86: 22-27.

5. Bahlmann, J., B. Ochwadt, and E. Schroder. 1965. Uber den Glucose-und Lactat-Stoffwechsel von isolierten Hundenieren. Arch. Gesamte. Physiol. Mens. Tiere. (Pfluegers). 286: 207-219.

6. Nishiitsutsuji-Uwo, J. M., B. D. Ross, and H. A. Krebs. 1967. Metabolic activities of the isolated perfused rat kidney. Biochem. J. 103: 852-862.

7. Reinecke, R. M. 1955. Renal arteriovenous changes in lactic acid and sugar in the eviscerated rat. Am. J. Physiol. 182: 243-246.

${ }^{2}$ Manuscript in preparation.
8. Steiner, A. L., A. D. Goodman, and D. H. Treble. 1968. Effect of metabolic acidosis on renal gluconeogenesis in vivo. Am. J. Physiol. 215: 211-217.

9. Bollman, J. L., and J. H. Grindlay. 1952. Measurement of renal gluconeogenesis. Am. J. Physiol. 170: 38-44.

10. McCann, W. P., and J. R. Jude. 1958. The synthesis of glucose by the kidney. Bull. Johns Hopkins Hosp. 103: 77-93.

11. Churchill, P. C., F. L. Belloni, and M. C. Churchill. 1973. Net renal glucose release in the rat. Am. J. Physiol. 225: 528-531.

12. Bergman, H., and D. R. Drury. 1938. The relationship of kidney function to the glucose utilization of the extra-abdominal tissues. Am. J. Physiol. 124: 279-284.

13. Reinecke, R. M. 1943. The kidney as a source of glucose in the eviscerated rat. Am. J. Physiol. 140: 276-285.

14. Smith, O. K., and C. N. H. Long. 1971. Renal gluconeogenesis in eviscerated diabetic rats. Proc. Natl. Acad. Sci. U. S. A. 68: 1618-1622.

15. Archer, L. T., B. Benjamin, M. M. Lane, and L. B. Hinshow. 1976. Renal gluconeogenesis and increased glucose utilization in shock. Am.J. Physiol. 231: 872-879.

16. Huggett, A. St. G., and D. A. Nixon. 1957. Use of glucose oxidase, peroxidase and 0-dianishidine in determination of blood and urinary glucose. Lancet. II: 368-370.

17. Nakagawa, H., and K. Nagai. 1971. Cold adaptation I. Effect of cold exposure on gluconeogenesis. J. Biochem. (Tokyo). 69: 923-934.

18. Itzhaki, R. F., and D. M. Gill. 1963. A micro-Biuret method for estimating proteins. Anal. Biochem. 9: 401410.

19. Snedecor, G. W., and W. G. Cochran. 1967. In Statistical Methods. Iowa State University Press, Ames, Iowa. 6th edition. 91-116.

20. Mainland, D. 1952. Elementary Medical Statistics; the Principle of Quantitative Medicine. W. B. Saunders Company, Philadelphia, Pa. 157.

21. Suda, M., K. Nagai, and H. Nakagawa. 1973. Studies on the circadian rhythm of phosphoenolpyruvate carboxykinase activity in rats. I. Mechanism of circadian increase in liver enzyme with special reference to hormonal and dietary effects. J. Biochem. (Tokyo). 73: 727-738.

22. Goldman, H. 1968. Oxytocin modulation of blood flow in the unanesthetized male rat. Am. J. Physiol. 214: $860-862$.

23. Goldstein, M. S., W. L. Henry, B. Huddlestun, and R. Lovine. 1953. Action of insulin on transfer of sugars across cell barriers: Common chemical configuration of substances responsive to action of the hormone. Am.J. Physiol. 173: 207-211.

24. Owen, O. E., P. Felig, A. P. Morgan, J. Wahren, and G. F. Cahill, Jr. 1969. Liver and kidney metabolism during prolonged starvation. J. Clin. Invest. 48: 574-583.

25. Goodman, A. D., R. E. Fuisz, and G. F. Cahill, Jr. 1966. Renal gluconeogenesis in acidosis, alkalosis and potassium deficiency: Its possible role in regulation of renal ammonia production. J. Clin. Invest. 45: 612-619. 